\title{
IN-VIVO TEST OF Chlorella vulgaris EXTRACT AS HEAT SHOCK PROTEINS INDUCTION OF CANTANG GROUPER (Ephinephelus fuscoguttatus-lanceolatus) INFECTED BY VIRAL NERVOUS NECROSIS
}

\author{
Amira Masitha $^{\mathrm{a}, *}$, Uun Yanuhar ${ }^{\mathrm{ab}}$, Asus Maizar Suryanto Hertika ${ }^{\mathrm{a}, \mathrm{b}}$ \\ ${ }^{a}$ Magister Program of Aquaculture, Faculty of Fisheries and Marine Sciences, Brawijaya University Malang, \\ Jl. Veteran No.1, Malang, Indonesia \\ ${ }^{\mathrm{b}}$ Department of Waters Resources Management, Faculty of Fisheries and Marine Sciences, Brawijaya \\ University Malang, Jl. Veteran No.1, Malang, Indonesia
}

*Corresponding author : amiramasitha21@gmail.com

\begin{abstract}
Cantang Grouper fish (Ephinephelus fuscoguttatus-lanceolatus) has a high value both in international and local markets. However, the production of these fishes has decreased due to viral infection kown as VNN (Viral Nervous Necrosis). In relation to viral infections, an induced Heat Shock Protein (HSP) by Chlorella vulgaris is an effort to be used as an anti-inflammatory agent because of VNN infection. This research aimed to know the potential of $C$. vulgaris extracts as an inducer of heat shock protein in Cantang Grouper fish. Method used in this research was experimental method using an in-vivo test treatment with $33 \mu \mathrm{g} / \mathrm{ml}$ of C.vulgaris extracts in Cantang grouper fish. There were four treatments applied, they were (A) control fish, (B) fish infected with VNN, (C) fish treated with C. vulgaris extracts, and (D) fish infected by the VNN and treated with $C$. vulgaris extracts. Based on the phytochemical test, $C$. vulgaris extracts contained alkaloids, terpenoids, and tannins. Control fish showed no apparent inflammatory reaction. Fish treated with $33 \mu \mathrm{g} / \mathrm{ml}$ of $C$. vulgaris extracts had low inflammatory response of HSP70. Fish infected by VNN and treated with 33 $\mu \mathrm{g} / \mathrm{ml}$ of $C$. vulgaris extract strengthened its inflammatory response as for fish infected by the VNN but without being treated by the extract showed very strong tissue inflammatory response. Results in this study indicate that that $C$. vulgaris extracts can inhibit the development of the virus and is capable to reduce the inflammatory response to Cantang grouper infected by VNN.
\end{abstract}

Keywords: Cantang grouper fish, Chlorella vulgaris, Heat Shock Protein, Viral Nervous Necrosis

\section{INTRODUCTION}

Grouper fish is one of the leading commodities of Indonesian fishery that has high economic value and high price and is the commodity of export. One of the grouper fishes cultivated in Indonesia is a Cantang grouper fish. The cantang grouper is the result of a hybrid between Tiger grouper (Epinephelus fuscoguttatus) and Kertang grouper (Epinephelus lanceolatus)[1]. This type of grouper is a hybrid grouper that was first produced at the Sabah University Marine Research Institute and has now become a very popular fish for marine aquaculture in the Southeast Asian region. Cantang grouper has several types of benefits such as rapid growth, tolerance to low water salinity and low water $\mathrm{pH}[2]$.
Grouper fish has a high value both in International and local markets. However, the productivity of hybrid Cantang grouper decreases due to environmental pressures including poor water quality, which makes the grouper become susceptible to viral, bacterial, stress infections resulting in poor growth and end of death [3]. Virus is one of the problems faced in the cultivation process of Cantang grouper. Viral infection is a serious illness that can lead to an acute mortality. One of the viruses that infect groupers is VNN (Viral Nervous Necrosis). VNN is one of the most prevalent epidemic diseases worldwide as reported in OIE (Office International dez Epizooties) [4]. Stadia larvae and juveniles are susceptible stadia infected with VNN causing 100\% mortality [5]. VNN generally attacks the organ system of the eye and brain nerves with 
symptoms that are quite specific as the fish exhibits abnormal swimming behavior and generally the fish stay at the base. Some of the symptoms of VNN-infected fish such as swirling fish; swimming at the bottom and showing unusual behavioral symptoms [6].

HSP (Heat Shock Protein) is naturally present in fish bodies that is physiologically a way of adaptation for fish to deal with stress [7]. HSP expression is influenced by various cell and cell tissues, in response to both biological stressors such as infectious pathogens, as well as abiotic stressors such as heat and cold sting, and environmental contaminants. These proteins have been categorized into several families based on their molecular weight such as HSP90 (85-90 kDa), HSP70 (68-73 kDa), HSP60, HSP47, and small HSPs (12-43 $\mathrm{kDa})$ [8]. The inflammatory reaction is one of the body's responses to viral infection. Inflammatory reactions can also be characterized by HSP expression [9]. Increased HSP levels serve to stimulate the inflammatory response due to viral infection. In the inflammatory pathway due to viral infection, the expression of HSP70 increases to provide cytoprotection by blocking the components of the inflammatory signal pathway, such as the NF- $\mathrm{KB}$ transcription factor [10].

Inducer HSP genes derived from natural ingredients have not been developed, one of them the use of bioactive microalgae compounds. Microalgae have great potential as an important source of energy in the future because it is abundant and has a complex content [11]. Microalgae are a group of autotrophic organisms that are known as potential sources of raw materials because they have very complex chemical content. The chemical composition of microalgae biomass is well studied and contains proteins, carbohydrates, lipids, pigments, vitamins, antioxidants, and trace elements. Proteins can be the most dominant compounds in microalgae such as Chlorella sp. [12]. Several types of marine algae such as red algae, brown algae, and green algae are potential source of bioactive compounds from nature and are very beneficial to the development of the pharmaceutical industry. Algae are capable of producing halogenated secondary metabolites that are as bioactive compounds [13].

C. vulgaris is one type of single-celled microalgae that can grow and be found in warm climates. $C$. vulgaris has many bioactive compounds include proteins, vitamins, minerals, carbohydrates, fats, chlorophyll and beta-carotene [14]. In some studies, it has been suggested that the protein pigments from Chlorella have many benefits. Some of the bioactive compound of them can be developed and applied as antibacterial [15] with measurable immune responses such as NF-kappa beta response [4] as well as antiviral and anti-inflammatory viral infections in the grouper [16]. The aims of this research to determine the effect of extract C. vulgaris with as an inducer of the HSP in VNN-infected Cantang grouper.

\section{MATERIALS AND METHOD}

\section{Place and Time of the Research}

The experiment and the analysis performed in this research were conducted in Situbondo Grouper Farming and Biotechnology Laboratory, Faculty of Fisheries and Marine Science, Malang. This research was conducted in February-May 2018.

\section{C. vulgaris Extraction}

Powder samples of $C$. vulgaris were collected from BPBAP Situbondo. C.vulgaris extraction processes were done by maceration process using methanol p.a with ratio 1:5 and incubate for 24 hours. Furthermore, the macerate samples were separated from the waste by filtering through a filter paper. Liquid phase of samples were concentrated by evaporating the solvent using a vacuum rotary evaporator with a low pressure at $40{ }^{\circ} \mathrm{C}$.

\section{Phytochemical Test}

Phytochemical tests were conducted to determine the presence or absence of secondary metabolite content of C.vulgaris including flavonoids, saponins, tannins, 
alkaloids, and terpenoids. Flavonoid screening was performed by dissolving the concentrated extract from $C$. vulgaris in hot methanol and added with $0.1 \mathrm{~g}$ of $\mathrm{Mg}$ powder and 5 drops of concentrated $\mathrm{HCl}$. Formation of orange color indicates the presence of flavonoids.

Saponin screenings were conducted by dissolving C. vulgaris extract in $10 \mathrm{~mL}$ of hot water for 10 seconds. Stable froth formation indicates the presence of saponins. Tannins screenings were conducted by dissolving concentrated $C$. vulgaris extract in $10 \mathrm{~mL}$ of distilled water and filtrate was added with 3 drops of $\mathrm{FeCl}_{3} 1 \%$. The formation of brownblack color indicates the extract from C.vulgaris contains tannins.

Identifications of alkaloid compounds were used by Mayer, Wagner, and Dragendorr methods [17], $0.5 \mathrm{~g}$ of extract was added with $1 \mathrm{~mL}$ of $2 \mathrm{M} \mathrm{HCl}$ and $9 \mathrm{~mL}$ of distilled water for 2 min., chilled and filtered. The filtrates were divided into 3 parts each added to the reagents of Mayer, Wagner, and Degendorff. If there are brown or red colored precipitate (Wagner), the white colored precipitate (Mayer) or orange colored precipitate (Dragendorff) indicates the extract is positive to contain alkaloids. Terpenoid screenings were taken to dissolve the concentrated $C$. vulgaris concentration in $0.5 \mathrm{~mL}$ of chloroform, then add $0.5 \mathrm{~mL}$ acetic anhydride and split the mixture with $2 \mathrm{~mL}$ of concentrated $\mathrm{H}_{2} \mathrm{SO}_{4}$ through the tube wall. The formation of a reddish brown color indicates the presence of terpenoid compounds.

\section{UV-Vis Tests}

UV-Vis test was conducted by inserting solution in the form of a solution of C.vulgaris extract into cuvet. Following by measuring uptake at a maximum wavelength, the absorbance range read on the spectrophotometer should be between 0.2 0.8 or $15 \%$ to $70 \%$ when reading as transmittance. Then record the results obtained. Furthermore, samples rate was calculated by entering the absorption price on the standard curve line equation.

\section{In-vivo Test of Crude Extract of C.vulgaris in Cantang Grouper Fish}

In-vivo tests were performed on Cantang grouper with length of $7-11 \mathrm{~cm}$. Their tests were performed by an oral method with the aid of feeding tube hose performed for three different days: 0 days, $5^{\text {th }}$ day, and $10^{\text {th }}$ day. This research conducted using a dose of $33 \mu \mathrm{g} / \mathrm{mL}$, where is referred to the previous clinical test [16] that is by using protein purification $C$. vulgaris.

\section{In-vivo Test of VNN in Cantang Grouper}

In-vivo tests using VNN was performed on the $5^{\text {th }}$ and $10^{\text {th }}$ days. VNN infection analysis was given by cutting small fish meat that was positively infected by VNN through oral method estimated to weigh $5 \mathrm{~g}$ per fish.

\section{Detections of Heat Shock Protein (HSP) using Immunohistochemistry (IHC)}

Detections of Heat Shock Protein (HSP) were conducted by using Immunohistochemistry (IHC) with the preparation of brain organ of fish treatment which was given HSP specific antibody. The organ tissues of the grouper fish were incubated in xylol for $5 \mathrm{~min}$. The organs were rinsed twice with alcohol in serial concentrations of $90 \%, 80 \%$ and $70 \%$ for 5 $\mathrm{min}$ in each process. The tissues slide preparations were rinsed with $\mathrm{ddH}_{2} \mathrm{O}$ for 5 min., 3 times, and the network slide preparation was stored in the refrigerator at $4{ }^{\circ} \mathrm{C}$ for overnight. The tissue preparation was washed with Phosphate Buffered Saline (PBS) $\mathrm{pH}$ 7,4 for 5 min., three times and incubated again with $3 \% \mathrm{H}_{2} \mathrm{O}_{2}$ for 10 min. Blocking of non-specific proteins was performed by incubation in $5 \%$ PBS or with $1-2 \%$ BSA. Tissue samples were incubated with antiHSP70 IgG anti-mouse primary antibody with a concentration of $1: 1000$ overnight, $40{ }^{\circ} \mathrm{C}$. The result was washed with PBS pH 7.4 for 5 min, three times, followed by incubation in an anti-IgG anti-rat secondary antibody with a 1:200 ratio for $1 \mathrm{~h}$. Tissue preparations were rinsed again with PBS pH 7.4 for 5 min., three times and incubated in 1:500 SA-HRP (Streptavidin-Horseradish Peroxidase) for 40 min. The incubation was then washed with 
PBS pH 7.4 for 5 min., three times and added DAB (3.3'-diaminobenzidine) chromogen for 20 min. Samples were washed with PBS pH 7.4 for 5 min., three times. After cleansing, it was rinsed with $\mathrm{dH}_{2} 0$ for 5 min., three times, then added counterstain with main hematoxyline (HE), $10 \mathrm{~min}$. The final preparation step was washing the tissues under running water for $5 \mathrm{~min}$, repeated three times. After the prepared slide was dried, it was then observed under a microscope [16].

\section{RESULTS AND DISCUSSIONS}

\section{Extract of $C$. vulgaris}

The result of the process of extraction of $C$. vulgaris by maceration process showed the form of a paste with $14 \mathrm{~g}$ of weight. For the percentage analysis, the yield of the extract can be calculated based on the final weight ratio (weight of the extract produced) with the initial weight (cell biomass weight used) multiplied $100 \%$ [18]. The yield of $C$. vulgaris extracts using methanol solvents were $7 \%$.

\section{Phytochemical Test}

The bioactive compounds contained in C. vulgaris extracts were flavonoids, saponins, tannins, alkaloids, and terpenoids. Identification results of the extract from $C$. vulgaris were shown in Table 1.

Tabel 1. Phytochemical Test Results of Crude Extract of C. vulgaris

\begin{tabular}{|c|c|c|c|}
\hline Compounds & Reagent & Result & Conclusion \\
\hline Flavonoid & $\begin{array}{l}\text { Concentr } \\
\text { ated } \\
\mathrm{HCL}+ \\
\mathrm{Mg}\end{array}$ & $\begin{array}{c}\text { Without } \\
\text { color }\end{array}$ & - (Negative) \\
\hline Alkaloid & $\begin{array}{c}\text { Bouchar } \\
\text { dat }\end{array}$ & $\begin{array}{c}\text { Brown } \\
\text { colored } \\
\text { precipitate }\end{array}$ & $+($ Positive $)$ \\
\hline Terpenoid & $\begin{array}{c}\text { Bouchar } \\
\text { dat }\end{array}$ & $\begin{array}{c}\text { Reddish } \\
\text { brown } \\
\text { colored } \\
\text { precipitate }\end{array}$ & $+($ Positive $)$ \\
\hline Tannins & $\begin{array}{c}\mathrm{FeCl}_{3} \\
1 \%\end{array}$ & $\begin{array}{l}\text { Brown- } \\
\text { black } \\
\text { color }\end{array}$ & $+($ Positive $)$ \\
\hline Saponins & $\begin{array}{c}\text { Concentr } \\
\text { ated } \\
\text { water+ } \\
\text { HCL }\end{array}$ & $\begin{array}{l}\text { Without } \\
\text { stable froth } \\
\text { formation }\end{array}$ & - (Negative) \\
\hline
\end{tabular}

The results of color stain were observed on silica gels. Phytochemical tests results showed that $C$. vulgaris extract had only three positive compounds from five compounds including alkaloids, terpenoids, and tannins. However, C. vulgaris extracts did not contain flavonoid and saponins. In contrast to other studies reporting that $C$. vulgaris extract contained flavonoids and saponins [19]. Differences in the content of the same species may occur. The content of phytochemical compounds is influenced by various factors, i.e. species, varieties, growth conditions, seasonal variations, processing methods and storage [20].

Alkaloid tests results were observed brown colored precipitate to indicate positive tests of the alkaloids class. Alkaloids are one of the secondary metabolisms found in plants. Alkaloids can triggers the nervous system, raising blood pressure, reducing pain, antimicrobials, sedatives, heart disease drugs and others [21].

Terpenoid test result was observed by the presence of brown orange colored precipitated on the tested solution. The terpenoids are cyclic or acyclic and often have alcohols, aldehydes, or carboxylic acids. Plants containing terpenoid compounds have ecological value because they work as antifungus, insecticides, anti-predator, antibacterial and anti-virus [22].

Tannin compounds showed a change in the color of brownish black colored that indicates a positive test on tannins groups. Tannins are a polyphenol compound having a large molecular weight comprising hydroxyl and carboxyl groups [23]. Tannins have antibacterial property through reactions to cell membranes, enzyme inactivation, and destruction or inactivation of genetic material functions [24]. Tannins also have a complex biological role ranging from protein precipitation to chelating metals. Tannins can also function as biological antioxidants [25].

\section{UV-Vis Test}

UV-Vis test results of $C$. vulgaris extracts were shown maximum peak at 663.1 $\mathrm{nm}$. Interesting peaks were also detected at 
$232.0 \mathrm{~nm}, 207.0 \mathrm{~nm}$, and $204.0 \mathrm{~nm}$. These wavelengths are meant for a detection of terpenoid compound. Terpenoid compounds have maximum wavelength uptake at $225 \mathrm{~nm}$ and $272.5 \mathrm{~nm}$ [26]. In other study, wavelengths above $200.80 \mathrm{~nm}$ also included bonded terpenoid compounds [27]. The wavelength indicates electron transition $\pi-\pi^{*}$ which is a typical UV spectral absorption for a triterpenoid compound having a chromophore of a non-conjugated double bond.

The highest wavelength result of 663.1 $\mathrm{nm}$ indicated a presence of chlorophyll a. Maximum absorption by chlorophyll a occurs at two wavelengths bands, i.e. 430 and 660 $\mathrm{nm}$ [28].

Tabel 2.Uv-Vis Test Results of C. vulgaris Extract

\begin{tabular}{cc}
\hline Wavelength (nm) & Abs \\
\hline 663.1 & 0.346 \\
423.0 & 0.690 \\
341.0 & 0.387 \\
232.0 & 1.021 \\
207.0 & 3.421 \\
204.0 & 3.377 \\
\hline
\end{tabular}

\section{In-vivo Test of $C$. vulgaris Extract to Cantang Grouper using Immunohistochemistry (IHC)}

Extracts of $C$. vulgaris were able to suppress inflammation at the time of VNN virus infection occurred. The responses were shown by detecting the induced heat shock proteins identified through immunohistochemistry methods. HSP expressions analysis was focused on target organs of the brain. Immunohistochemistry is able to visualize cell components, such as proteins or other macromolecules in tissue samples. Immunohistochemistry (IHC) analysis using immunoRatio-derived software resulted in a different percentage of $\mathrm{DAB}$ between the control fish group and the other three treatment fish.

\section{Control Fish}

The results of observation on the control fish using immunohistochemistry and continued analysis using immunoRatio obtained DAB percentage of 21\% (Figure 1).
This showed that the target gene (HSP) presented in the control fish was expressed by $21 \%$. HSP remained expression even under normal conditions. Under normal conditions HSP is a protein that plays a role in the formation of protein structures, this is called protein folding [29]. In the observation of damage level in brain organ of control fish, found no damage either necrosis, vacuole or hypertrophy

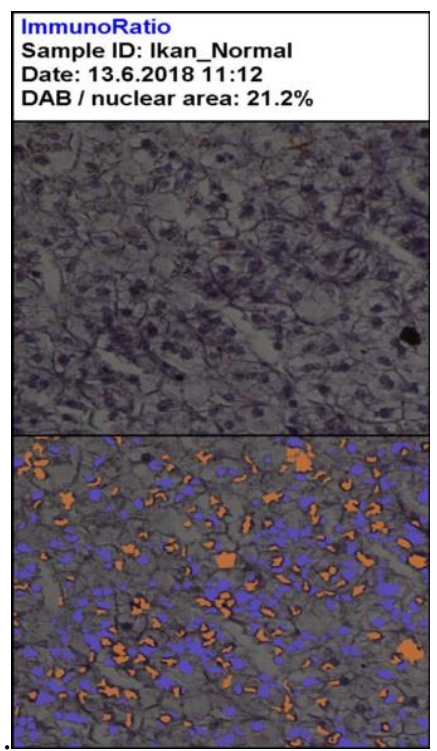

Figure 1. ImmunoRatio Results of Cantang Grouper Brain (Control Fish)

\section{Fish with VNN Treatment}

Immunohistochemistry results of fish brain with VNN treatment were obtained DAB percentage value of $63.7 \%$ (Figure 2). It shows that the target gene (HSP) was presented in VNN-treated fish expressed by 63.7\%. High HSP expression values were indicated that the cell is stressed due to VNN infection. VNN is one of the triggers that affect HSP expression. When the cell has stress, the HSP will experience an increase in expression because the HSP is trying to protect the cell to avoid changes in protein structure formation [29]. 


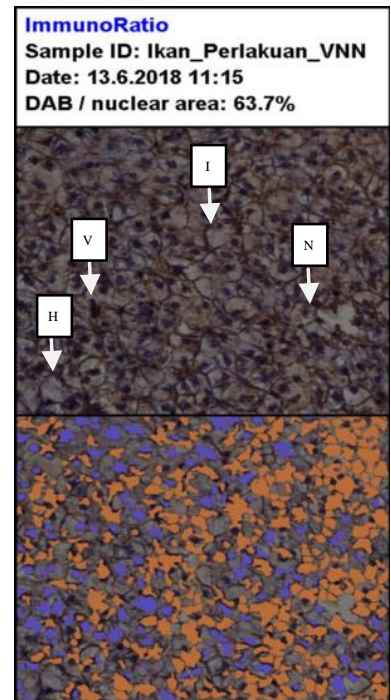

Figure 2. ImmunoRatio Results of Cantang Grouper Brain with VNN Treatment. (H) Hypertrophy, (N) Necrosis, (I) Inclusion body, (V) vacuole

The observation on brain organ of the VNN-infected Cantang grouper showed that VNN infection causes the cells to changed in shape and size. Cells with hypertrophy are described by increasing volume (cell magnification) $(\mathrm{H})$. There is also a damaged cell (necrosis) $(\mathrm{N})$ causing the cell to be destroyed, furthermore, it remains as an empty space in the brain tissue of $\mathrm{VNN}$-infected groupers. Necrosis is the occurrence of cell death that suspected as a result of systemic infection, i.e. through the bloodstream then reaches to the brain and inflicts damage to the organ's composing tissue [30].

In the brain organ of Cantang grouper treated with VNN infection showed inclusion body (I). Inclusion body is characteristic of virus infection in target organs. Inclusion body is an early process of necrosis cells with black spots on the cytoplasm [31]. There is also damage to the brain organ with marked vacuole $(\mathrm{V})$. Vacuoles appeare as a result of cell swelling that indicates cell degeneration [32]. On observation of damage level of brain organ of VNN-treated fish as a whole, it is seen that there is hollow tissue. This indicates the fatal damage caused by infection of VNN.

\section{Fish with Treatment of Extract of C.vulgaris}

Immunohistochemistry results of brain organ fish treatment extract from $C$. vulgaris obtained DAB percentage value of $44.6 \%$ (Figure 3). This suggests that the target genes (HSP) present in fish treated with $C$. vulgaris extract were $44.6 \%$. and on observation of the damage levels of brain organ on $C$. vulgaris treatment fish, found no damage such as necrosis, inclusion body, and vacuole.

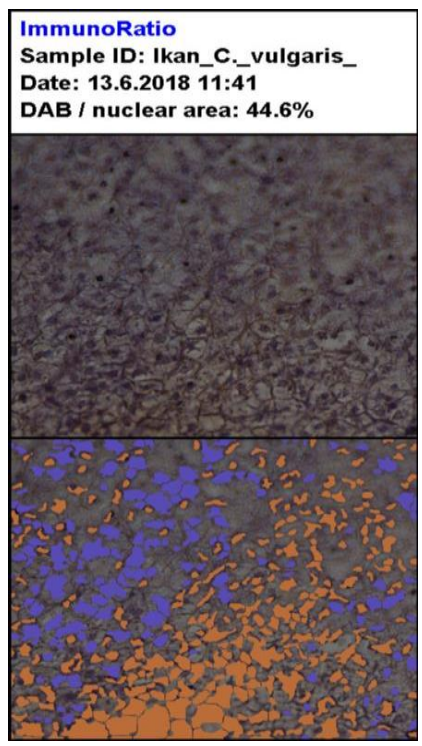

Figure 3. ImmunoRatio Results of Cantang Grouper Brain with Treatment of Extract of C.vulgaris

\section{Fish with Treatment of Extract of C.vulgaris and VNN}

Immunohistochemistry of fish brain treated with $C$. vulgaris and VNN obtained the value of DAB percentage $60.4 \%$ (Figure 4). This suggests that the target genes (HSP) in fish treated with extracts from $C$. vulgaris and infected by the VNN were expressed by $60.4 \%$. This result was lower compared to the percentage of DAB fish infected by the VNN but without extract treatment. The level of stress on fish was lower due to the administration of $C$. vulgaris extract that could improve the immune system of the Cantang grouper. Condition of the immune system of fish infected by VNN increased due to the application of $C$. vulgaris extract, 
furthermore, the body was ready and in good condition when the VNN started to infect the fish.

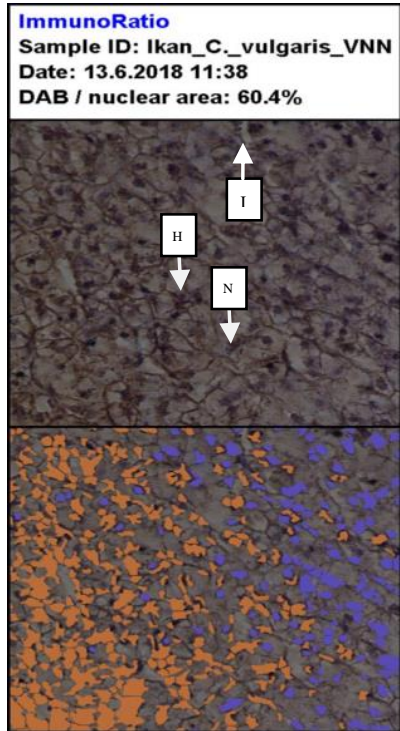

Figure 4. ImmunoRatio Results of Cantang Grouper Brain with Treatment of Extract C.vulgaris and VNN. (I) Inclusion body, (N) Necrosis, (H) Hypertrophy

Damage levels of the brain treated with C. vulgaris extract and VNN infection showed inclusion body, necrosis, and hypertrophy, however, the damage was smaller compared to those infeted by VNN infection but without extract treatment (Figure 4). In the observation of brain organ, there were some black spots detected indicating inclusion body (I), there was also necrosis or cell death indicated by arrow $(\mathrm{N})$ with the empty space in brain organ. In this treatment also appeared to occur hypertrophy $(\mathrm{H})$; it was a swelling or addition of volume cells due to viral infection. From the above data, there is a significant difference between the HSP profile on the control fish group and to the three fish with the treatment.

VNN is one example of the RNA genome virus that is composed of two molecules (RNA1 and RNA2) [33]. VNN infects the brain organ of grouper fish in an instant by directly attacking the fish receptors. VNN is a virus that does not have an envelope, then the virus spreads to the brain through the blood circulation.
Infection by this virus triggers the occurrence of inflammation in the fish tissue. Inflammation occurs in response to infection, heat stroke or cellular stress. VNN will trigger active immune cells to protect tissues and cells in fish. The cells in the fish body will experience stress which will cause the response to stress in the form of heat shock response (HSR). Under stressful conditions, HSP creates protein aggregation, refolds damaged proteins and lowers irreversible proteins. As a pro-inflammatory mediator, HSP can release necrotic, non-necrotic substances into the extracellular environment, resulting in various immune and inflammatory responses, including activation of immune system effector and cytokine release [9].

Extracting marine microalgae C.vulgaris with a dose of $33 \mu \mathrm{g} / \mathrm{ml}$ can inhibit the development of the virus qualitatively by being able to reduce the inflammatory response from tissue in the Cantang groupers. The compounds in C.vulgaris extract have the ability to block the adhesion of pathogens. The general mechanism of antiviral activity of the microalgae active compound against the wrapped virus may be based on a positively charged shield of the viral glycoprotein, when the virus attaches to the cell, the active compound in the microalgae can against with the viral amino acid glycoprotein and block the viral adsorption process [34].

The active compounds in $C$. vulgaris extract can also be used as an antiinflammatory in $\mathrm{VNN}$-infected grouper shown by heat shock protein expression response (HSP). Based on the results from control fish with labeling using $\operatorname{IgG}$ anti HSP 70 antimouse inflammatory responses do not appear the reaction to inflammation, in fish treatment of extract of $C$. vulgaris $33 \mu \mathrm{g} / \mathrm{ml}$ HSP-70 responses to low inflammatory responses, and treatment of extract of C. vulgaris $33 \mu \mathrm{g} / \mathrm{ml}$ and VNN inflammatory response strengthened and tissue inflammatory response with VNN treatment alone is very strong.

As an anti-inflammatory molecule, the expression infection the Heat shock protein 70 (HSP70) increases to provide cytoprotection by inhibiting components of the inflammatory signal pathway, such as the transcription 
factor NF- $\mathrm{KB}$. Increased HSP levels serve to stimulate an inflammatory response to a type of Toll receptor 2 (TLR2)/TLR4/CD14 based on the mechanisms that lead to NF- $\kappa B$, TNF- $\alpha$, IL1- $\beta$ and IL- 6 production activities. HSP can block the NF- $\mathrm{KB}$ pathway by increasing the I$\kappa \mathrm{B} \alpha$ gene expression. Knowlton explained that HSP can increase immune modulation by providing a regulation target of $\mathrm{T}$ cell-specific [35].

\section{CONCLUSIONS}

Present study has the same result as the previous one showing that $C$. vulgaris extract may improve the induction response from heat shock proteins as anti-inflammatory markers for VNN-infected grouper fish tissue. The responses were expressed by the expression of HSP 70 both qualitatively and quantitatively. Morphology analysis results showed necrosis, tissue vacuolation, and tissue inclusion due to VNN antigen virus infection. It is important to perform a study on the purification of $C$. vulgaris extracts to obtain natural compounds that can be clinically anti-inflammatory as a result of VNN RNA virus infection.

\section{ACKNOWLEDGMENT}

This work was funded by the Ministry of Research, Technology and Higher Education of Republic of Indonesia through the PDUPT Program at University of Brawijaya with contract no: 460.137/UN10.C10/PN/2017.

\section{REFERENCES}

[1] S. Ismi, Y. N. Asih, and Daniar Kusumawati, "Peningkatan Produksi Dan Kualitas Benih Ikan Kerapu Melalui Program Hibridisasi," J. Ilmu dan Teknol. Kelaut. Trop., vol. 5, no. 2, pp. 333-342, 2013.

[2] R. F. Firdaus, L. S. Lim, G. Kawamura, and R. Shapawi, "Assessment on the acceptability of hybrid grouper, Epinephelus fuscoguttatus $q \times$ Epinephelus lanceolatus $\hat{\delta}$ to soybean meal-based diets," AACL Bioflux, vol. 9, no. 2, pp. 284-290, 2016.

[3] N. M. Noor, S. K. Das, Z. C. Cob, and M. A. Ghaffar, "Effects of Salinities and Diets on Growth of Juvenile Hybrid Grouper, Epinephelus fuscoguttatus $\times \mathrm{E}$. lanceolattus," Turkish J. Fish. Aquat. Sci., vol. 18, pp. 1045-1051, 2018.

[4] U. Yanuhar, "The Function of Receptor Protein Humpback Grouper Cromileptes Altivelis in Expression and Proliferation of CD4 and CD8 cells in Defence Immunity of Viral Nervous Necrotic Infection," Int. J. Biosci. Biochem. Bioinforma., vol. 1, no. 2, pp. 119-124, 2011.

[5] M. E. J. Zorriehzahra et al., "Isolation and confirmation of viral nervous necrosis (VNN) disease in golden grey mullet (Liza aurata) and leaping mullet (Liza saliens) in the Iranian waters of the Caspian Sea," Vet. Microbiol., vol. 190, pp. 27-37, 2016.

[6] C. C. Lin, J. H. Y. Lin, M. S. Chen, and H. L. Yang, "An oral nervous necrosis virus vaccine that induces protective immunity in larvae of grouper (Epinephelus coioides)," Aquaculture, vol. 268, no. 1-4 SPEC. ISS., pp. 265273, 2007.

[7] H. Cahyadi, E. Tyasrini, and J. Lucianus, "Peranan Heat Shock Protein pada Patogenesis Penyakit Infeksi dan Penyakit Autoimun," JKM, vol. 2, no. 3, pp. 110-116, 2004.

[8] H. Park, I. Y. Ahn, and E. L. Hye, "Expression of heat shock protein 70 in the thermally stressed Antarctic clam Laternula elliptica," Cell Stress Chaperones, vol. 12, no. 3, pp. 275-282, 2007.

[9] U. Yanuhar, R. Christiawan, M. Mahmudi, A. M. Sh, and D. Arfiati, "Heat Shock Protein ( Hsp ) Response Within RNA Viral Nervous Necrosis 
( VNN ) that Infect of the Humpback grouper Cromileptes altivelis," pp. 9-13, 2015 .

[10] C. C. Chang et al., "Heat shock protein 70 protects against seizure-induced neuronal cell death in the hippocampus following experimental status epilepticus via inhibition of nuclear factor- $\kappa \mathrm{B}$ activation-induced nitric oxide synthase II expression," Neurobiol. Dis., vol. 62, pp. 241-249, 2014.

[11] Sukarni, Sudjito, N. Hamidi, U. Yanuhar, and I. N. G. Wardana, "Potential and properties of marine microalgae Nannochloropsis oculata as biomass fuel feedstock," Int. J. Energy Environ. Eng., vol. 5, no. 4, pp. 279-290, 2014.

[12] C. V. Viegas et al., "Algal products beyond lipids: Comprehensive characterization of different products in direct saponification of green alga Chlorella sp.," Algal Res., vol. 11, pp. 156-164, 2015.

[13] U. Yanuhar, Mikroalga Laut Nannochloropsis Oculata: Malang: UB Press, 2016.

[14] G. Tang and P. M. Suter, "Vitamin A, nutrition, and health values of Algae: Spirulina, chlorella, and dunaliella," $J$. Pharm. Nutr. Sci., vol. 1, no. 2, pp. 111$118,2011$.

[15] U. Yanuhar, "The Role of Immunogenic Adhesin Vibrio alginolyticus $49 \mathrm{kDa}$ to Molecule Expression of Major Histocompatibility Complex on Receptors of Humpback Grouper Cromileptes altivelis," World Acad. Sci. Eng. Technol., no. 67, pp. 968-973, 2010.

[16] U. Yanuhar and A. Khumaidi, "The application of pigment-protein fraction from Nannochloropsis oculata on $\beta$-actin response of Cromileptes altivelis infected with viral nervous necrosis," $J$. Akuakultur Indones., vol. 16, no. 1, p. 22,
2017.

[17] P. Tiwari, B. Kumar, M. Kaur, G. Kaur, and $\mathrm{H}$. Kaur, "Phytochemical screening and Extraction: A Review," vol. 1, no. 1, 2011.

[18] R. N. Sani, F. C. Nisa, R. D. Andriani, and J. M. Maligan, "Analisis Rendemen dan Skrining Fitokimia Ekstrak Etanol Mikroalga Laut (Tetraselmis chuii)," $J$. Pangan dan Agroindustri, vol. 2, no. 2, pp. 121-126, 2014.

[19] D. Fithriani, S. Amini, and S. Melanie, "Uji Fitokimia , Kandungan Total Fenol Dan Aktivitas Antioksidan MikroalgA Spirulina sp ., Chlorella sp ., dan Nannochloropsis sp . Activity of Microalgae Spirulina sp ., Chlorella sp . and," JPB Kelaut. dan Perikan., vol. 10, no. 2, pp. 101-109, 2015.

[20] Y. H. Pyo, Y. J. Jin, and J. Y. Hwang, "Comparison of the effects of blending and juicing on the phytochemicals contents and antioxidant capacity of typical Korean kernel fruit juices," Prev. Nutr. Food Sci., vol. 19, no. 2, pp. 108$114,2014$.

[21] R. Aksara, W. J. A. Musa, and L. Alio, "Identifikasi Senyawa Alkaloid Dari Ekstrak Metanol Kulit Batang Mangga ( Mangifera indica L )," J. Entropi, vol. 8, no. 1, pp. 514-519, 2013.

[22] E. Widiyati, "Penentuan Adanya Senyawa Triterpenoid Dan Uji Aktivitas Biologis Pada Beberapa Spesies Tanaman Obat Tradisional Masyarakat Pedesaan Bengkulu," J. Gradien, vol. 2, no. 1, pp. 116-122, 2006.

[23] P. P. Sari et al., "Identifikasi Dan Uji Aktivitas Senyawa Tanin Dari Ekstrak Daun Trembesi (Samanea saman (Jacq.) Merr) Sebagai Antibakteri Escherichia coli (E. coli)," J. Kim., vol. 9, no. 1, pp. 27-34, 2015. 
[24] B. Martono and T. Setiyono, "Skrining fitokimia enam genotipe teh," J. Tidp, vol. 1, no. 2, pp. 63-68, 2014.

[25] L. P. Malangngi, M. S. Sangi, and J. J. E. Paendong, "Penentuan Kandungan Tanin dan Uji Aktivitas Antioksidan Ekstrak Biji Buah Alpukat (Persea americana Mill .)," J. Mipa Unsrat Online, vol. 1, no. 1, pp. 5-10, 2012.

[26] M. D. Astuti, E. M. Kuntorini, and F. E. P. Wisuda, "Isolasi Dan Identifikasi Terpenoid dari Fraksi n-Butanol Herba Lampasau (Diplazium esculentum Swartz),"Valensi, vol. 4, no. 1, pp. 20 24, 2014.

[27] Zulfadli, N. Ferdinal, and B. Arifin, "Isolasi Terpenoid Fraksi Aktif Antioksidan Dari Daun Andong (Cordyline fruticosa [L.] A. Cheval)," $J$. Kim. Unand, vol. 4, no. 1, pp. 67-70, 2015.

[28] K. Khotimah, Darius, and B. B. Sasmito, "Ujia aktifitas senyawa aktif alga coklat (Sargassum fillipendulla) sebagai antioksidan pada minyak ikan lemuru (Sardinella longiceps)," Thpi Student J., vol. I, no. 1, pp. 10-20, 2013.

[29] T. indah B. S, I. K, and Soehardjo, "Peran Heat Siiock Protein (HSP) Terhadap Penyakit Rongga Mulut," IJD, vol. 14, 2006.

[30] E. H. Hardi, E. Harris, A. M. Lusiastuti, L. M. Perairan, U. Mulawarman, and K. Timur, "Karakteristik dan Patogenisitas
Streptococcus Agalactiae Tipe $\beta$ hemolitik dan Non-hemolitik pada Ikan Nila," vol. 12, no. 2, pp. 152-164, 2011.

[31] E. Novisa, Tarsim, and E. Harpeni, "Pengaruh Jintan Hitam (Nigella sativa) Terhadap Histopatologi Organ Kakap Putih (Lates calcarifer) Yang Terinfeksi Viral Nervous Necrosis Secara Buatan," J. Rekayasa dan Teknol. Budid. Perair., vol. III, no. 2, pp. 383-388, 2015.

[32] Rizka Rahmana Putri, U. Yanuhar, and A. M. S. H, "Perubahan Struktur Jaringan Mata Dan Otak Pada Larva Ikan Kerapu Tikus (Cromileptes altivelis) Yang Terinfeksi Viral Nervous Necrosis (Vnn) Dengan Pemeriksaan Scanning Electron Microscope (SEM)," MSPi STUDENT J., vol. I, no. 1, pp. 1-10, 2013.

[33] C. Tan et al., "Determination of the complete nucleotide sequences of RNA1 and RNA2 from greasy grouper (Epinephelus tauvina) nervous necrosis virus, Singapore strain," J. Gen. Virol., vol. 82, no. 3, pp. 647-653, 2001.

[34] M. F. D. J. Raposo, A. Maria, M. Bernardo, R. Manuel, and S. Costa, "Bioactivity and Applications of Polysaccharides from Marine Microalgae," Polysaccharides, pp. 1-38, 2014.

[35] A. A. Knowlton, "NFkB, heat shock proteins, HSF-1, and inflammation," Cardiovasc. Res., vol. 69, no. 1, pp. 7-8, 2006. 